\title{
Diagnostic and prognostic value of cancer stem cell marker CD44 and soluble CD44 in the peripheral Blood of patients with oral Squamous cell carcinoma
}

Aya K. Khamis*, Hamed A. Fouad, Hanaa S. Raslan, Mohamed M. Fata, Amira I. Fayad

Alexandria University, Egypt

*Corresponding Author: Aya K. Khamis: ayakhamis88@gmail.com

\section{Abstract}

Background: Head and neck cancer is a major health problem. Recent studies on the pathobiology of oral squamous cell carcinoma (OSCC) have led to the discovery of a small population of cancer cells with a consistent behavior with the features of cancer stem cells (CSCs). CSCs are required and responsible for initiation, maintenance and recurrence of disease. Molecular markers are commonly used for the identification of CSCs. CD44 is the most reported CSC marker in OSCC. The aim of the study was to evaluate and correlate the expression of CD44 in different histopathological grades of OSCC, as well as to assess the diagnostic and prognostic value of soluble CD44 (CD44sol) in peripheral blood of patients.

Materials and methods: Fifteen patients with OSCC were included; biopsies were histologically evaluated using haematoxylin and eosin. Serial sections were immunohistochemically stained by monoclonal antibody to CD44. The intensity of immunostaining of CD44 was calculated. Enzyme-linked immunosorbent assay (ELISA) method was used to determine the concentration of CD44sol in the blood serum.

\footnotetext{
Competing Interests: The author have declared that no competing interests exists.
} 
Results: All grades of OSCC showed membranous immunosignaling of CD44. The well, moderately and poorly differentiated OSCC cases showed weak, moderate and intense positive membranous immunosignaling of CD44 respectively. CD44sol levels were significantly higher in OSCC patients than they were in control groups. Soluble CD44 serum levels were significantly higher in poorly differentiated than they were in moderately and well differentiated.

Conclusion: CSCs detection in fixed human tissue and CD44sol detection in peripheral blood using ELISA seemed to be a promising method and may have a diagnostic and prognostic value in management of OSCC.

Keywords: Caner stem cell, CD44, soluble CD44, stem cells and oral squamous cell carcinoma.

\section{Introduction}

Head and neck cancer is a major health problem throughout the world.(1) Head and neck squamous cell carcinoma (HNSCC) is one of the most common malignancy in humans and one of the most common malignant tumors of the oral and maxillofacial regions. (2) In 2008; 263,900 new cases of head and neck cancer were diagnosed and 128,000 deaths related to this malignancy have occurred worldwide.(1)

Estimation reveals that 11 out of every 100,000 adults diagnosed every year with oral cancer. (3) The standard of care for patients with OSCC includes platinum-based chemotherapeutic drugs, surgery and radiotherapy. (2) Surgical treatment and frequent local recurrences significantly reduce patient's quality of life.(4)

\section{Oral Squamous Cell Carcinoma}

Cancer that forms in tissues of the oral cavity or the oropharynx is referred as the oral cancer. Among all oral mucosal origin cancers, about $90 \%$ are squamous cell carcinoma (SCC).(5)

Oral cancer holds the eighth position in the cancer incidence ranking worldwide, with epidemiologic variations between different geographic regions. (It is the third most common malignancy in south-east Asia.) $(2,6)$ 
Oral cancer is twofold more prevalent in men than in women, due to increased alcohol consumption and tobacco habits ranging from sixty to seventy years of age.(7)

The tongue is the most common location; how-ever, it can also affect the lip mucosa, buccal mucosa, gingiva, floor of the mouth and palate. (8)

Despite advances in therapy, survival rates have remained static and mortality from OSCC remains high. It is therefore essential to develop a better understanding of the biology of this disease to develop more effective therapies. (9)

Studies on the pathobiology of OSCC have led to the discovery of a specific limited population of cancer cells that are highly tumorigenic, capable of selfrenewal and behave as tumor progenitor cells.(9, 10) Such behavior is consistent with the features of cancer stem cells (CSCs).(11)

\section{Stem Cells}

Stem cells are pluripotent cells with the capacity for self-renewal and differentiation into various types of adult cells.(12) Ever since their discovery in 1960s, stem cells have been "the secret of life" itself.(13) Stem cells are roughly categorized as embryonic stem cells (ESCs), mesenchymal stem cells (MSCs) and induced pluripotent stem cells (iPSCs).(14)

Embryonic stem cells are derived from the inner cell mass of preimplantation embryos and demonstrate excellent pluripotency.(15) Mesenchymal stem cells are multipotent stromal cells that have been isolated from both adult and fetal tissues and are defined as adherent fibroblast-like cells.(16)

The more recently introduced iPSCs show enormous promise for disease modeling and regenerative medicine. This is because their pluripotency is similar to that of ESCs and their utilization is without ethical controversy. $(14,17)$

A better understanding of the mechanisms involved in tumor biology will pave the way for prevention and early detection of the tumors. CSCs and normal stem cells possess similar characteristics such as:

1. Self-renewal capacity

2. Differentiation capacity to mature progeny

3. Ability to survive for a long time

4. Resistance to damaging agents

5. Anchorage, independent growth and metastasizing capacity

6. Active telomerase expression (telomere "shortening" leads to chromosomal instability)

7. Active membrane transporter activity (responsible for chemotherapy resistance)

\section{Cancer Stem Cells}

According to the American Association for Cancer Research (AACR) workshop on CSCs in 2006,(18) neoplastic stem cells were defined as; cells within the tumor that are capable of self-renewal as well as of differentiation into various types of cells of the same line, ensuring phenotypic heterogenicity of the tumor and serving as progenitor cancer cells. 


\section{History of the Cancer Stem Cell}

The concept of CSC first originated in 1855, when the German pathologist Rudolf Virchow (19) proposed that cancers arise from the activation of dormant embryonic cell remnants. The idea that cancer can originate from a small population of cells with stem cell properties was proposed about 150 years ago by the Italian surgeon Francesco Durante in 1874.(20)

Regarding solid tumors, in 2003 Al-Hajj et al (21) first identified and isolated a population of CSCs from breast cancer, showing that only a subset of them, which exhibited expression of the surface markers CD44+/ CD24- or low had tumorigenic capacity. They experimentally confirmed the ability of transplanted stem cells to restore a phenotypically heterogeneous structure of a tumor.

Cancer stem cells were found in several other cancers, including liver and melanoma.(11) Also, populations of CSCs were identified and isolated in other solid tumors as; brain(22), prostate(23), colorec $\neg \operatorname{tal}(24)$, pancreatic(25) and lung cancers.(26)

Research studies are dominated by the hypothesis that there is a small population of cells within the main tumor mass containing stem cell features. $(9$, 27) CSCs are required and responsible not only for initiation, but also for maintenance and recurrence of disease.(9)

\section{Origin of Cancer Stem Cells}

Two main hypotheses exist regarding the origin of CSC, they either originates from a somatic tissue cell that undergoes genetic mutations, becomes cancerous and acquires stem cell characteristics, or from embryonic or adult stem cells as a result of genetic mutations.(28)

\section{Properties of Cancer Stem Cells}

The intrinsic properties of CSCs, resides in their ability to duplicate, differentiate and control homeostasis.(20) CSCs possess five major potentials which render them 'immortal': 1) self-renewal capacity, 2) high proliferation ability, 3) drug resistance, 4) high migration capacity and 5) differentiation into multiple mature progeny.(29)

\section{Niches}

Cell 'niche' is formed of a heterogeneous group of cells (fibroblasts and endothelial cells) and cellular matrix.(30) It has been proven that microenvironment plays an undeniable role in the biology and development of CSCs.(31) It may also play a pivotal role in tumor response to therapeutics.(30)

\section{Uses of Cancer Stem Cells in Treatment}

It is believed that existence of CSCs may be the reason for the lack of effectiveness of conventional treatment methods.(32) In OSCC, where the first 
and fundamental method of treatment involves surgical removal of the tumor, CSCs might have already metastasized at the time of surgery. They are probably responsible for tumor recurrence.(33)

Cancer stem cells show more resistance to chemo- and radiotherapy than non-stem cells. (34) Targeted elimination of these cells was considered to provide a new framework for head and neck cancer treatment.(35)

\section{Role of Cancer Stem Cell in Progression and Metastasis}

Cancer stem cells play a role not only in the creation of cancer, but also in its evolution, metastasis and recurrence. CSCs have an important role in cancer therapy and the resistance towards chemotherapeutic agents. $(29,36)$

\section{Epithelial-Mesenchymal Transition and Cancer Stem Cells}

Epithelial-mesenchymal transition allows epithelial cell to assume a mesenchymal cell characteristics, which possesses enhanced motility and invasiveness (37) CSCs are responsible of metastasis and invasion .(38)

EMT is involved in the acquisition of CSC properties. Eventually, epithelial cells lose their cell attachment and migrate elsewhere.(39) Loss of cell polarity is a critical step in EMT.(40) Also loss of E-cadherin appears to be correlated with tumor progression and a crucial step in the progression from a benign to a malignant tumour. (41) These facts supports the fact that EMT leads to recurrence, metastasis and poor clinical prognosis.(11)

\section{Methods for CSCs Identification and Isolation}

\section{Surface Antigens}

As CSCs constitute a small percentage (less than 10\%) of cancer cells, they may be extremely challenging to characterize.(33) Molecular markers are one of the most commonly used strategies for the identification of CSCs. (11) CSCs markers includes CD34, CD133, CD24, CD29, CD31 and CD44.(42, 43) The identification and characterization of the CSCs may aid in tailoring efficacious targeted therapies and minimizing recurrences.(9) it will also aid patient characterization according to their tumor aggressiveness and prognosis. (44)

The CSC hypothesis has also been coined for OSCC; among the cell surface markers reported as CSC markers in OSCC are; CD44, CD133 and CD24.(45-47) Among them, CD44 is the most reported CSC marker in OSCC.(48-50)

\section{Markers in Solid Tumors}

\section{CD44}

CD44 is an integral cell membrane glycoprotein, (51) it is involved in cell migration and adhesion. CD44 is believed to be a key marker for identification of CSCs in SCC.(52) CD44 binds to several ligands; hyaluronic acid (HA) is the most prominent among them.(53) $\mathrm{HA}$ is a linear polymer of repeating disaccharide. CD44 has tens of isoforms, the most common one is standard CD44 
(CD44st). Hyaluronic acid is a major constituent of the extracellular matrix and is believed to create a low resistance matrix, allowing enhanced cell motility. (54)

CD44 is of particular interest because it seems to be a relatively early marker of malignancy.(55) CD44 isoforms are expressed in variable degrees in normal and tumor cells, which prove that it exhibits a normal cellular function. (56)

\section{Expression of CD44 in Non Tumor Tissue}

CD44 is widely expressed on many types of epithelium and mesenchymal elements. (57) In normal upper aerodigestive tract epithelium, CD44 is expressed at the basal cell layer. However, in dysplastic epithelium and invasive OSCC, its expression may involve all layers of the epithelium in most of the cases. $(58,59)$

\section{In OSCC}

The existence of CSCs in OSCC was first described in 2007 by Prince et al (9) who used CD44 to isolate CSCs. These cells were capable of tumor formation when implanted in immunosuppressed mice.

\section{Soluble CD44}

Considering the implication of CD44 in the activation of cell replication, its antiapoptotic activity and its potential as a marker of CSCs in epithelial tumors,(60) it was decided to study the role of soluble CD44 (CD44sol) in head and neck tumors by focusing on the identification of its soluble fraction in the peripheral blood in OSCC patients.

In pathological conditions such as cancer, the extracytoplasmic domain of the CD44 receptor detaches and is released into biological fluids as D44sol).(48) The determination CD44sol could be a simple, noninvasive tool in cancer screening and in treatment follow up.(61) A drop is the level of CD44sol was observed following tumour resection, which assumed that, most likely it resulted from tumor cells.(62) Soluble CD44 appears to be a possible screening marker routine screening owing to early diagnosis of head and neck tumors.(63)

The Enzyme-linked immunosorbent assay (ELISA) system is cited as the most sensitive, well-established and widely available protein-based testing platform for the detection of cancer in body fluids. (64)

\section{Soluble CD44 in Non Cancer and cancer Patients}

CD44sol level in the serum of normal individuals was $(2.7 \pm 1.1 \mathrm{IU} / \mathrm{ml})$. In HNSCC, a study showed that CD44sol was elevated in oral rinses of patients with disease invading mucosa and not elevated in any of the normal controls. Kawano et al (65) found that post treatment CD44sol level was significantly lower than the pretreatment levels of HNSCC patients.

In 2007 Franzmann et al (55) concluded that CD44sol was elevated in the majority of HNSCC cases and distinguished cancer from benign disease with high specificity. In 2012 Franzmann et al (66) found that high levels of CD44sol was significantly associated with HNSCC. Concluding that oral rinse levels of CD44sol and protein appear to hold promise for detection of HNSCC.

Due to the implication of CD44 in the activation of cell replication, its antiapoptotic activity and its potential as a marker of CSCs in epithelial tumors, as well as the role of CD44sol in HNSCC; the present study was conducted to 
evaluate the expression of CD44 in tumor tissue and its soluble fraction in the peripheral blood in OSCC patients.

The aim of the present study was to evaluate and correlate the expression of CD44 in different histopathological grades of OSCC, as well as to assess the diagnostic and prognostic value of CD44sol in peripheral blood of cancer and non cancer patients.

\section{Material and Methods}

\section{Peripheral Blood Sample}

Fifteen peripheral blood samples were from fifteen patients clinically diagnosed with OSCC were selected from the Cranio-Maxillofacial and Plastic Surgery Department at the Faculty of Dentistry, Alexandria University. Three peripheral blood samples were from squamous cell papilloma patients and three peripheral blood samples from three healthy individuals serving as negative control. Written informed consents were taken from all the patients.

\section{Tumor Tissue Sample}

Fifteen surgical specimens were taken from the same fifteen selected patients. Three surgical specimens were taken from squamous cell papilloma, serving as negative control. Written informed consents were taken from all the patients.

\section{Methods}

Biopsies were taken from the tumor tissue and fixed in $10 \%$ neutral buffered formalin, processed and embedded in paraffin wax using the conventional procedures. Serial sections of 3-4 $\mu \mathrm{m}$ thick were placed on glass slides and stained using hematoxylin and eosin $(\mathrm{H} \& \mathrm{E})$ for routine histopathological examination. This was followed by histological grading of the tumor into well, moderate and poorly differentiated SCC.

The serum was removed from the clot or red blood cells as soon as possible after clotting and separation. Samples were stored frozen at $-20^{\circ} \mathrm{C}$. The ELISA plate and the standard curves whole kit were stored at $2^{\circ} \mathrm{C}$.

\section{Immunohistochemical interpretation}

Immunohistochemical marker of mouse monoclonal antibody MGMT Ab-1 (Clone MT 3.1). Cat. \#MS-470-R7 (7.0ml) (Thermo Fisher Scientific, CA, USA) was used. Strept-Avidin Biotin-peroxiadase complex method (LSAB) was used (Lab vision corporation). Serial sections $4-5 \mu \mathrm{m}$ thick were taken from the previously used paraffin blocks for H\&E. The slide will be mounted on poly-Llysine coated glass slides. Two sections will be obtained for the positive test slides and third one for the negative control by omitting the primary antibody. The tissue sections were deparaffinized in xylene, rehydrated in graded ethanol and incubated in $0.3 \%$ hydrogen peroxide solution to block the endogenous peroxidase. The specimens were washed with an appropriately characterized, diluted and were incubated with the primary antibody of MGMT. Exposure to biotinylated link antibody and labeled streptavidin-biotinperoxidase complex was done to bind the primary antibody. Staining was completed by incubation in 
substratechromogen solution and hematoxylin counter stain. Immuno-expression of MGMT will be evaluated by using image analyzer to evaluate both mean area percent and mean optical density. The results were recorded and statistically analyzed using one-way analysis of ANOVA.

\section{ELISA interpretation}

Human CD44 ELISA kit, for the quantitative level of CD44 (standard and variant isoforms) in the sample was used. * Preparation was done according to the manufacturer instructions.

The difference in the concentration of circulating human CD44 in OSCC samples in different grades were estimated using the one-way analysis of ANOVA, and estimated in tumours exhibiting or lacking invasion into the surrounding structures using student (t) test.

\section{Results}

\section{Clinical results}

In the present study, a total of fifteen patients with OSCC were included. The patients' age ranged between 52 and 71 . The mean age was found to be $(61.8$ \pm 6.3 years). Ten patients $(66.7 \%)$ were males and five patients $(33.3 \%)$ were females.

\section{Histopathological Results}

The microscopical examination revealed that five cases $(33.3 \%)$ were of the well differentiated type, eight cases $(53.3 \%)$ were moderately differentiated OSCC and two cases $(13.3 \%)$ were of the poor differentiated type.

\section{Immunohistochemical Results}

All oral squamous cell papilloma cases $(n=3)$ showed positive immunoreactivity for CD44 in certain areas. The immunoreaction appeared as brownish membranous reaction in the basal and suprabasal layers.

All grades of OSCC cases showed membranous immunosignaling of CD44. The nuclei, cytoplasm and keratin were free from any reaction in all the samples. The well differentiated OSCC cases showed weak positive membranous immunosignaling of CD44 in the peripheral epithelial cells forming the epithelial pearls and nests (Fig 1). The moderately differentiated OSCC cases demonstrated moderate positive membranous immunoreaction of CD44 (Fig 2). In the poorly differentiated type of OSCC, intense CD44 immunopositivity was detected in the malignant epithelial cells. It showed the highest number and greatest intensity of immunopositive cells (Fig 3). 
Research Article

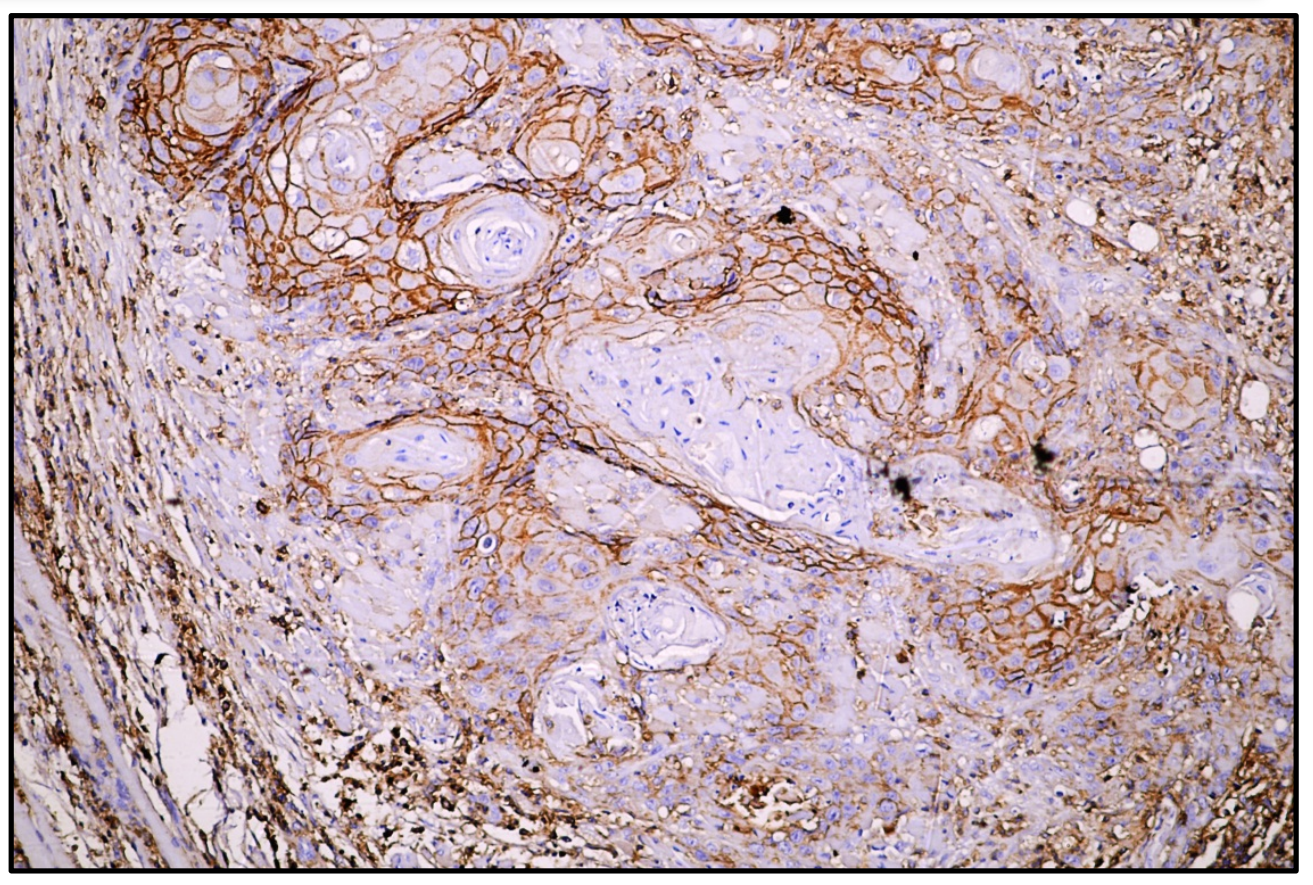

a)

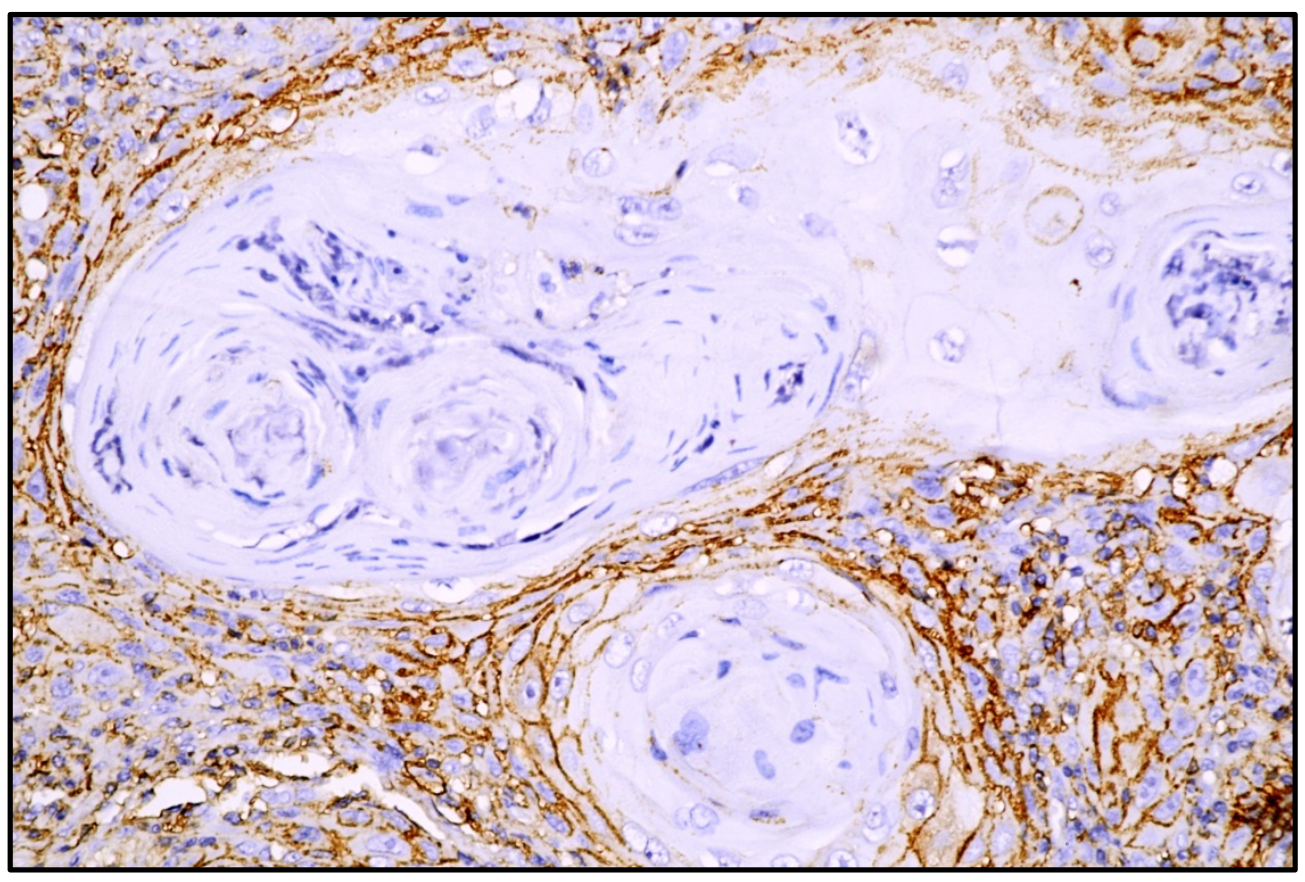

b)

Fig 1: a) Well differentiated OSCC revealing weak membranous immunoreactivity of CD44 in the peripheral epithelial cells of the keratin pearl. Notice that the keratin and the central cells are immunonegative (Immuno stain of CD44 x 100). b) Higher magnification of Well differentiated OSCC (Immuno stain of CD44 x 200). 


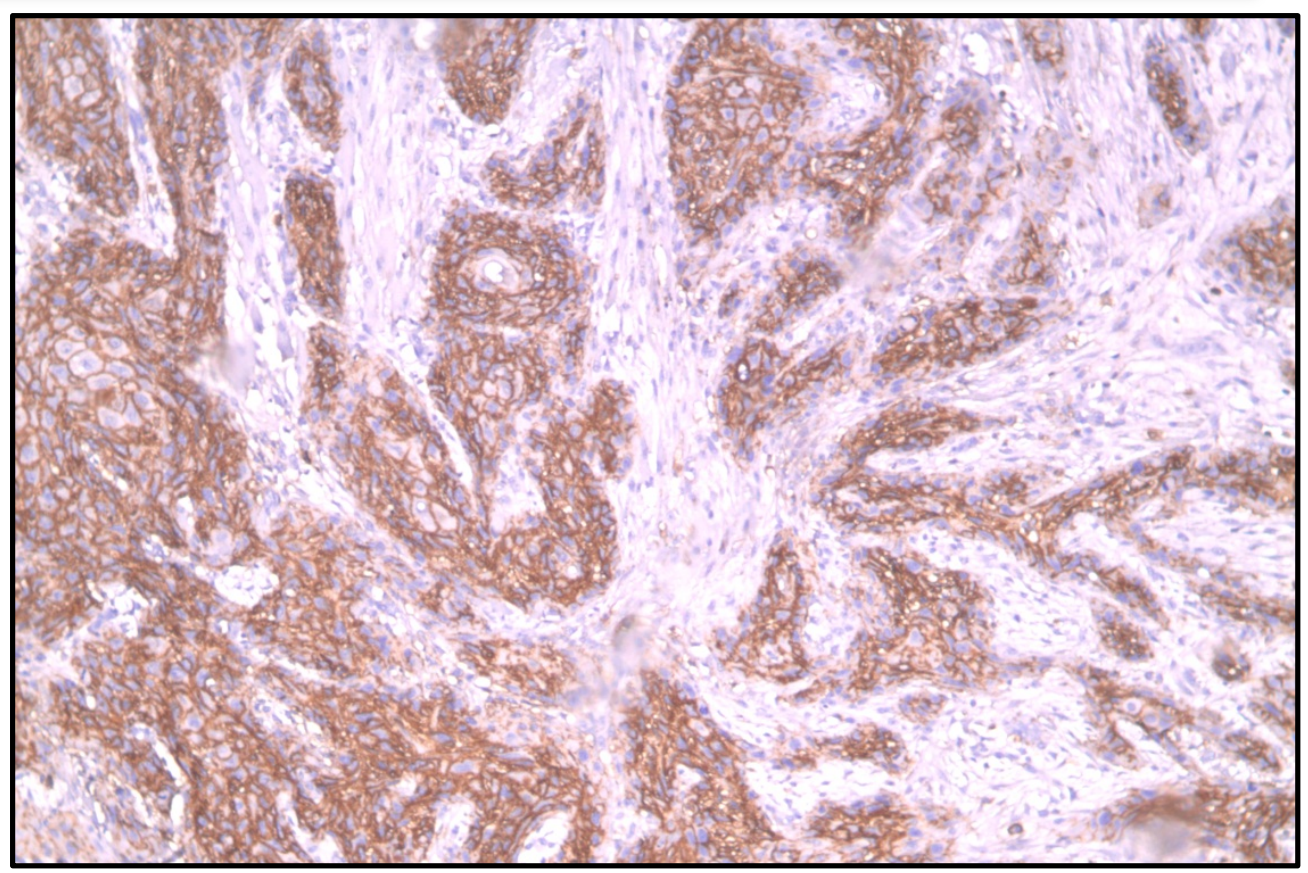

a)

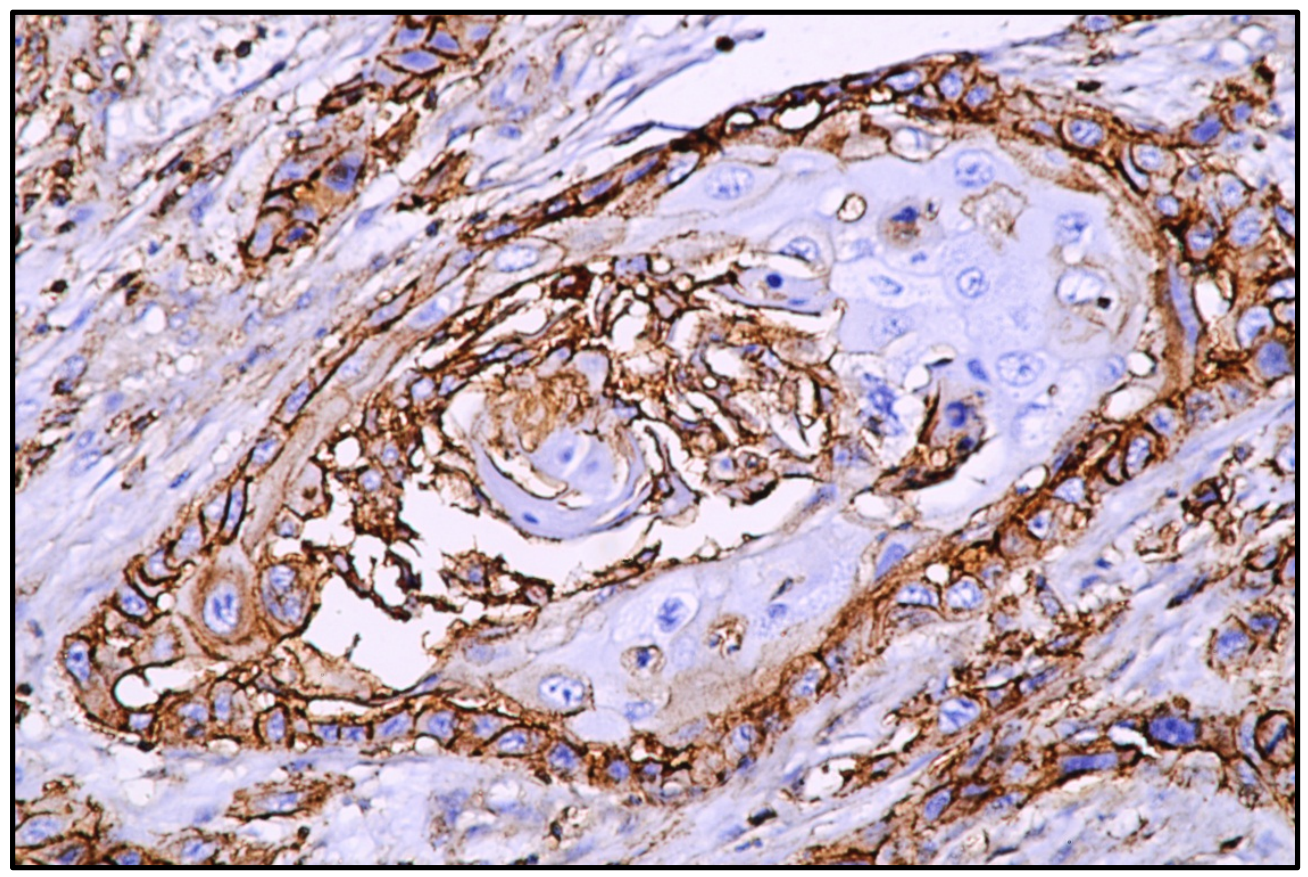

b) 
Research Article

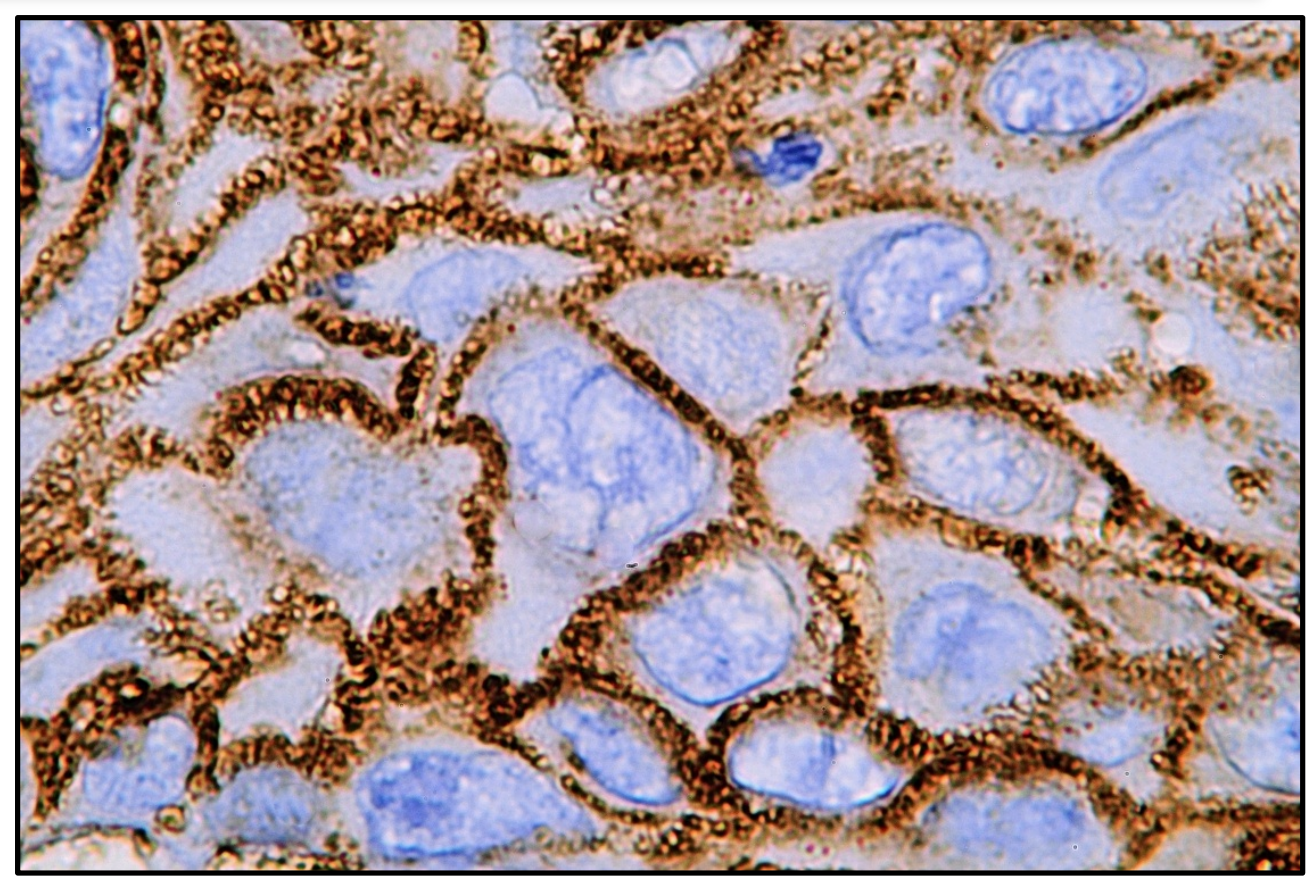

c)

Fig 2. a) Moderately differentiated OSCC showing moderate positive membranous immunoreactivity (moderate intensity) of CD44 in almost all anaplastic cells forming malignant cell nests (Immuno stain of CD44x 100). b) Moderately differentiated OSCC showing evident moderate positive membranous immunoreactivity of CD44 mainly in the peripheral malignant cells of the nest and some of the central cells. Most of the central cells are immunonegative (Immuno stain of CD44 x 200). c) Moderately differentiated OSCC showing moderate positive membranous reaction of CD44 of all the malignant epithelial cells forming the cell nest, notice the desmosomes. The nucleus and cytoplasm are immunonegative (Immuno stain of CD44 x 1000). 
Research Article

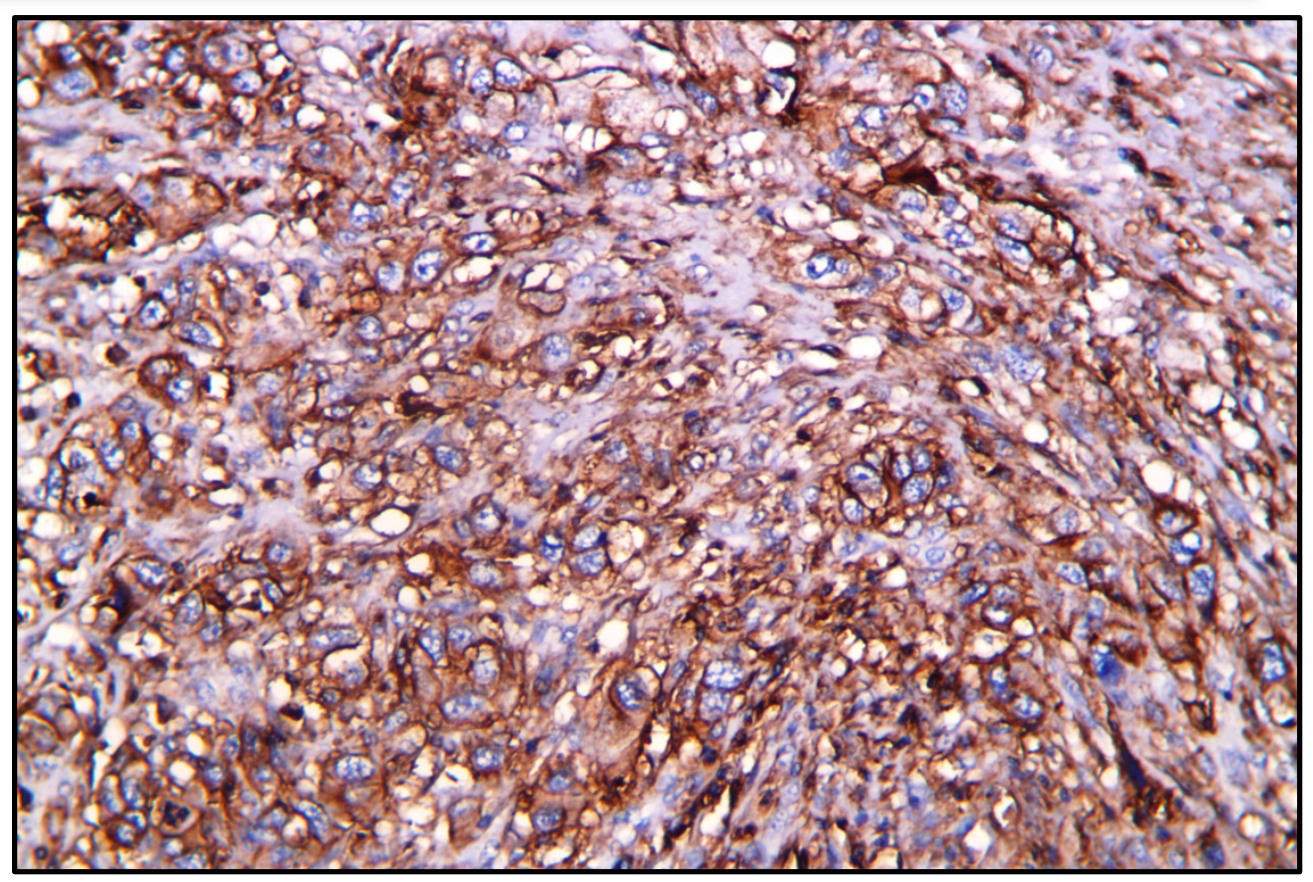

a)



b)

Fig 3: a) Poorly differentiated OSCC showing intense positive membranous reaction of CD44 in the anaplastic cells forming the sheets of malignant epithelial cells. Nucleus and cytoplasm are immunonegative (Immuno stain of CD44 x 200). b) Poorly differentiated OSCC revealing intense positive membranous positive reaction of CD44 in the anaplastic malignant epithelial cells forming the sheets. It also shows abnormal mitosis (arrow) (Immuno stain of CD44 x 400). 


\section{CD44 Expression in Correlation with Histological Grade of OSCC}

Both mean area percent and mean optical density of CD44 expression in all OSCC cases were correlated with their histological grade using the image analyzer computer system.

The difference in mean CD44 area present and optical density between the well, moderately and poorly differentiated groups using F-test (ANOVA) revealed significantly higher difference at $(\mathrm{p}<0.001)$.

\section{ELISA Results}

CD44sol levels were significantly higher in OSCC patients than they were in patients with benign epithelial tumor and in healthy individuals (18.66 \pm 3.52 $\mathrm{IU} / \mathrm{ml}, 6.5 \pm 1.32 \mathrm{IU} / \mathrm{ml}$ and $2.8 \pm 0.53 \mathrm{IU} / \mathrm{ml})$ respectively at $(\mathrm{p}<0.001)$.

Soluble CD44 serum levels were significantly higher in poorly differentiated than they were in moderately and well differentiated $(26.07 \pm 2.96$ vs. $18.55 \pm 1.33$ vs. $15.88 \pm 1 \mathrm{IU} / \mathrm{ml}$ ) respectively. In moderately differentiated CD44sol serum levels were significantly higher than they were in well differentiated. CD44sol serum levels were significantly higher in OSCC patients exhibiting invasion into the surrounding structures compared to others lacking invasion at $(\mathrm{p}<0.001)$.

\section{Discussion}

The present study was carried out on patients with OSCC. The clinical data in the present work revealed that the age range of the OSCC patients with a mean age $61.8 \pm 6.3$ years. This finding was in accordance with most studies. (8) It has been accepted for a long time that carcinomas are associated with old age. (67) This may be due to the longer duration of exposure to environmental carcinogens, as well as the cumulative effect of these carcinogens.(68)

The current study results were in contrast to those of Sharma et al, (69) who stated that the incidence of OSCC was increasing in younger individuals; this may be due to the increase intensity of bad habits engagement.

In the present study, males $(66.6 \%)$ were more commonly affected than females $(33.3 \%)$. This was in accordance to many studies that supported the fact that oral cancer is more common in males than in females.(70) The reported gender differences were attributed to heavier indulgence in risk habits by men and exposure to sunlight (for lip cancer) as a part of outdoor occupations.(67)

However, those results were in contrast to those found by Patel et al (71) who found that there was an increasing incidence of OSCC in females especially young ones. The increasing incidence of females affected with SCC may be attributed to the increase in the use of tobacco and alcohol drinking in females nowadays,(72) HPV (73) and increased longevity of females.(68)

The clinical distribution of OSCC in the current study revealed that the lateral side of the tongue was the most prevalent site of occurrence for OSCC $(46.7 \%)$ followed by the alveolar mucosa (26.7\%). These results were in consistence with many investigators who reported that the tongue was the most common site for OSCC. $(8,74)$

The results were in contrast to those found by Effiom et al (75) who found that the mandibular alveolar ridge followed by the tongue were the most common 
sites. They attributed that to the tendency of the carcinogens in tobacco, alcohol or dissolved food to pool in gravity dependent areas of the mouth.

CD44 has been selected as a marker for identifying CSCs in SCC. It was usually accepted as a poor prognosis marker.(76) A small subpopulation of positive cells (CSCs) was identified in OSCC samples.(77)

Regarding the expression of CD44 in OSCC tissue samples, CD44 was detected in OSCC tissue samples by IHC analysis. It was also observed that CD44 was abundantly expressed in all OSCC samples tested $(\mathrm{n}=15)$ and therefore conform to data collected by most of the researchers.(78-87)

The present study results demonstrated that the overexpression of the adhesion molecule CD44 had significantly higher association with the histological grade in OSCC. Intense, moderate and weak expressions were associated with poorly, moderately and well differentiated histological grades respectively. Hence CD44 overexpression could be used in OSCC staging as; a sign of aggressiveness, a prognostic factor in OSCC and to assist in treatment.

The current study results were in accordance with; Ghuwalewala et al (83) who found that CD44high CD24low cell population displayed increased CSC and EMT properties. They also showed high tumorigenic potential, drug resistance, invasion and metastasis.

De Andrade et al (84) study showed that CD44high derived tumors were heterogeneous and showed differential expression pattern of CSC and EMT markers. According to Ohkoshi et al (85) the up regulation of CD44 serves as a survival mechanism, allowing cells to escape apoptosis in response to DNA damage repair in HNSCC.

Baschnagel et al (86) concluded that High CD44 expression is associated with poor prognosis in HNSCC patients treated with chemo-radiation. Dunkelet al (87) immunohistochemistry of CD44 may be useful in identification of patients with poor prognoses. This may eventually aid in treatment planning.

Kokko et al (78) and Kanke et al (80) who found that CD44 overexpression could be used as; a prognostic factor in HNSCC and as a sign of aggressiveness.

Lindquist et al (79) observed that high intensity CD44 staining was correlated to poor. Chen et al (82) concluded that patients with lower CD44 expression had a better survival prognosis.

Maula et al (81) study concluded that CD44 may be a useful predictive and prognostic tool in the clinical management of HNSCC.

Wang et al (56) reported that; different CD44 isoforms expressions were associated with HNSCC lymph node metastasis, advanced $\mathrm{T}$ status, perineural invasion, shorter survival, distant metastasis and failure of radiotherapy.

In contrast to the current study results, Faber et al (88) found that the staining pattern shown in immunohistochemistry revealed a monotonic staining pattern of almost all cells except stromal and vascular cells. Similarly, Han et al (89) found that CD44 was abundantly expressed in all HNSCC samples tested.

Prince et al (9) who first postulated CD44+ cells as CSCs reported that, CD $44+$ cancer cells typically comprise $<10 \%$ of the cells in HNSCC tumor. A possible reason might be the different experimental methods of CD44 detection. However, the limitation of their study was that in two-thirds of the samples used, it was necessary to pass the cells initially in immunocompromised mice to have a sufficient number of tumor cells to isolate CSCs. This could have altered the expression patterns of native CSCs. 
Pries et al (90) found that CD44+ CSCs may play a key role in the establishment of permanent HNSCC cell lines and might drive the progression and metastasis of HNSCC.

The tumorigenicity of CD44+ cells of HNSCC seemed also to increase when such cells co-express additional markers such as the ALDH or CD24.(91, 92) Campos et al (91) observed that $\mathrm{ALDH}+$ and $\mathrm{CD} 44+$ have higher proliferation rates and are more resistant to apoptosis than control cells (ALDH- CD44-).

Though CD44 is generally accepted as a substitute marker for HNSCC CSCs.(9) In contrast to the present study results a recent study by $\mathrm{Oh}$ et al,(93) reported that; CSCs themselves hold the ability to be heterogonous due to various genetic alterations.

The discrepancy between Oh et al (93) results and the present study results may be explained as follows, CD44- HNSCC cells have stem cell trait due to three reasons. Firstly, brief culture can make tumor cell viability more stable because the procedure used itself is toxic to tumor cell. Secondly, the environment of an in vitro short-term culture may select for the CD44- HNSCC cells with CSC traits. Thirdly, a high proportion of cells in HNSCC may have the potential to drive cancer progression.

Similarly, Bloor et al (94) found no evidence of association between CD44 expression and prognostic significance. This may be due to the limited number of patients evaluated in the previous two studies.

There are several possible explanations for these discrepant results. First of all, many of the previous studies used antibodies for specific variants of CD44. Although the expression of specific variants may be reduced in tumors with a worse prognosis while the overall CD44 expression may not.

Second, CD44 was highly expressed on stromal and inflammatory cells, which were excluded on performing flow cytometric analysis. Although it is possible on histologic study to differentiate between tumor and non tumor cells, it may not be as accurate at excluding these cells.

Third, different studies used different antibodies, making comparisons across reports from different research groups difficult. Certain CD44 variant domain epitopes might have been hidden and not recognized by some antibodies because of posttranslational changes that alter the three-dimensional conformation of the protein.

Soluble CD44 was evaluated in blood serum of patients with different primary cancers, (95-99) as well as in oral rinses of patients with HNSCC. (100) Elevated CD44 serum levels have been found for several other tumor types using ELISA analysis.(97) The finding of high CD44sol levels in patients affected by cancer might be related to the amount of the extracellular fraction of the CD44 antigen released by stem cells that remain on the tumor mass. $(60,101)$

In the present study, ELISA was used to evaluate the concentrations of CD44sol in patients with OSCC in relation to benign epithelial tumors patients and normal donors (healthy individuals). The results revealed a significant correlation at $(\mathrm{P}>0.001)$ between serum $\mathrm{CD} 44$ concentration in patients with OSCC, patients with benign tumors patients and normal donors (healthy individuals).

Serum CD44 levels were also correlated with tumor histological differentiation. There was a significant correlation at $(\mathrm{P}>0.001)$ between serum CD44 concentrations in patients with different histological grades of OSCC. 
Patients with poorly differentiated tumors had the highest concentration of CD44sol in their serum.

These results were in accordance to the results found by Patel et al (101) who concluded that circulating tumor cells exhibit immense potential in enhancing diagnosis, prognosis and response to therapy in solid malignancies.

Faber et al (88) found a significantly higher difference between concentration of CD44sol in serum of HNSCC patients in comparison to healthy controls. This accordance may be because they similarly measured the total quantity of CD44sol including all isoforms just as the present study.

Kawano et al (65) concluded that there were significant differences in pretreatment median serum level of soluble CD44v5, CD44v6 and CD44st in the patient group and the control. They also found that the median post-treatment serum levels of CD445, CD44v6 and CD44vst were significantly lower than the pre-treatment levels. They also proposed that the determination of serum levels of CD44sol before treatment might be used to provide the clinician with important additional information for prognosis of patients with HNSCC. Their study confirmed that the serum CD44sol concentration might help guide the practitioner to select the appropriate therapy.

Lin et al (102) revealed that the CD44sol levels in the peripheral blood of patients with locally advanced oral or oropharynx cancer were much higher than they were in healthy people. The pretreatment CD44sol levels of greater than fivefold were associated with the prognosis of the disease and the prediction of recurrence in patients who had received chemo-/radiotherapy. A high CD44sol level was significantly related to poor prognosis.

Franazmann et al concluded in his studies $(55,66,103)$ that, oral rinse CD44sol level appears to hold promise for early detection of HNSCC. The revealed data showed that the CD44sol test was very specific for HNSCC. Additionally, Periera et al (104) reported that the salivary CD44sol levels were much higher in HNSCC patients than in patients with benign disease.

Similarly Chen et al (76) proposed that, detecting the CD44sol levels in oral rinses might be a good prognostic prediction. Among the advantages of oral rinses are their convenience and noninvasiveness. The present study measured the level of CD44sol in the peripheral blood, which is supposed to be more accurate. This may be because it omits the human factor and physiological variations that may alter the final results.

The present study results were in contrast to the findings reported by Van Hal et al (96), who did not find significant differences between the CD44v6 plasma levels in HNSCC patients and control groups. A reason might be the measurement of different isoforms of CD44. In the present study all standard and variant isoforms were measured. An explanation for the findings of Van Hal et al might be given by Herold-Mende et al (105) who concluded that the expression of CD44v5 and CD44v6 was unaltered in HNSCC patients.

Also in contrast to the present study results, Franzmann et al (103) found that the plasma level of CD44sol was not significantly different between oral cancer patients and normal controls. This might be attributed to the relative small burden of oral tumors that may not alter the basal level of CD44sol.

In accordance to the present study results, in laryngeal carcinomas, the high expression of CD44 appears to correlate with poor prognosis because of regional or distant metastasis and radiotherapy resistance.(60, 106) Allegra et al (60) 
concluded that the determination of CD44sol levels as a potential diagnostic marker of laryngeal cancer in the saliva of patients with laryngeal carcinoma using ELISA seems to be a promising method.

For other types of cancer CD44v6 has already been shown to be a potential marker of prognosis. Saito et al (95) postulated that the serum concentration of CD44v6 and its expression in tumors were associated significantly with the depth of invasion of the tumor, lymph node metastasis and clinical stage in patients with diffuse type gastric carcinoma. He also found that there was a significant correlation to the stage of primary tumor expansion, lymph node metastasis or distant metastasis.

Guo et al (62) concluded that there was a significant correlation between serum CD44 concentration in patients with metastatic colon cancer and serum CD44 concentration in normal donors. Elevated serum CD44 levels in these patients may be due to active shedding of CD44 molecules by the tumor cells. In contrast to Lein et al (107) who found no increase in the standard and variant CD44 proteins in the serum of patients with urological malignancies (prostate cancer, renal cell cancer or bladder cancer).

In the present study the analysis of the malignant cells invasion into the surrounding structures in relation to the concentrations of CD44sol in serum revealed significant difference.

Several other studies postulated that; CD44sol was identified in serum, plasma or urine of patients with different tumors. Serum level of CD44sol was correlated with tumor progression in a wide variety of human malignancies.(62, $95,108)$

In contrast to the current study results, Faber et al (88) found that there was no correlation between concentration of CD44sol in serum of HNSCC patients and the tumor invasion.

In the present work the analysis of the clinical data in relation to the concentrations of CD44sol in serum revealed an absence of significant differences between the histological grades according to tumor site and tumor size. These results were in accordance to Kawano et al (65) who found that there was no significant correlation between the serum levels of soluble CD44v5, CD44v6 and CD44st and the clinicopathological variables.

The determination of CD44sol levels in the serum of patients with OSCC using ELISA, compared with other screening tests as PSA for prostate cancer (109) and the Pap test for cervical cancer,(110) seems to be a promising diagnostic test in terms of high sensitivity and specificity, low cost and noninvasiveness of the technique.

\section{Conclusions}

Based on the present study results, the following conclusions were obtained:

1. Cancer stem cells can be reliably detected immunohistochemically in fixed human tissues of OSCC and in all the control specimens.

2. CD44 marker can be used to identify specific subpopulations of CSCs that are resistant to therapy and require more aggressive treatment strategies. 
3. The pattern of CD44 immunosignals was expressed in the cell membrane of all OSCC cases studied.

4. Computer based image analysis showed that there was a significant difference between mean optical density and mean area percent of CD44 expression in different grades of OSCC cases as well as control cases.

5. A directly proportional relation was present between CD44sol value in peripheral blood of OSCC patients evaluated using ELISA and the amount of CSCs detected by immunohistochemistry (CD44) in fixed human tissues of OSCC.

6. CD44 expression level either in the soluble form or in the cell membrane was associated with tumor aggressiveness and invasion indicating the importance of this molecule in progression of OSCC.

7. CD44 detection in OSCC tissue and determination of CD44sol levels in the serum of patients with OSCC using ELISA seemed to have a potential prognostic and predictive value in the management of OSCC.

8. The serum level of CD44sol might be a useful marker for tumor screening.

\section{Recommendations}

1. Further studies with longer follow-up and a larger number of patients are needed.

2. Further studies should be done to evaluate the therapeutic implications of CD44 in cancer treatment.

3. Further studies should be done to evaluate effectiveness of CD44 marker in detecting occult carcinomas.

4. Peripheral CD44sol level evaluation is recommended to provide presurgical information about the primary tumor grade and regional extension.

5. CD44sol detection using ELISA could potentially be used in community outreach programs, since sample collection and its laboratory processing are so simple.

\section{References}

1. Jemal A, Bray F, Center MM, Ferlay J, Ward E, Forman D. Global cancer statistics. CA: a cancer journal for clinicians. 2011 Mar-Apr;61(2):69-90.

2. Moazeni-Roodi A, Allameh A, Harirchi I, Motiee-Langroudi M, Garajei A. Studies on the Contribution of Cox-2 Expression in the Progression of Oral Squamous Cell Carcinoma and HRas Activation. Pathology \& Oncology Research. 2016:1-6.

3. Joseph LJ, Goodman M, Higgins K, Pilai R, Ramalingam SS, Magliocca K, et al. Racial disparities in squamous cell carcinoma of the oral tongue among women: A SEER data analysis. Oral Oncology. 2015;51(6):586-92.

4. NCI. Cancer Trends Progress Report2009/2010.

5. Sinha N, Mukhopadhyay S, Das DN, Panda PK, Bhutia SK. Relevance of cancer initiating/stem cells in carcinogenesis and therapy resistance in oral cancer. Oral Oncology. 2013;49(9):854-62.

6. WHO. The World Oral Health Report 2003. Geneva2003. 
7. Rasool M, Khan SR, Malik A, Khan KM, Zahid S, Manan A, et al. Comparative Studies of Salivary and Blood Sialic Acid, Lipid Peroxidation and Antioxidative Status in Oral Squamous Cell Carcinoma (OSCC). Pak J Med Sci. 2014 2014/05//;30(3):466-71.

8. Silva LP, Gonzaga AKG, Serpa MS, Nascimento GJF, Sobral APV. Immunohistochemical expression of cyclooxygenase-2 and cyclin-D1 in oral squamous cell carcinoma. Journal of Oral and Maxillofacial Surgery, Medicine, and Pathology. 2017.

9. Prince ME, Sivanandan R, Kaczorowski A, Wolf GT, Kaplan MJ, Dalerba P, et al. Identification of a subpopulation of cells with cancer stem cell properties in head and neck squamous cell carcinoma. Proceedings of the National Academy of Sciences. 2007 January 16, 2007;104(3):973-8.

10. Zubair H, Azim S, Srivastava SK, Bhardwaj A, Marimuthu S, Patton MC, et al. Cancer Stem Cells. Stem Cells in Toxicology and Medicine: John Wiley \& Sons, Ltd; 2016. p. 375-413.

11. Zhang Z, Filho MSA, Nör JE. The biology of head and neck cancer stem cells. Oral Oncology. 2012;48(1):1-9.

12. Somorjai IM, Lohmann JU, Holstein TW, Zhao Z. Stem cells: a view from the roots. Biotechnol J. 2012 Jun;7(6):704-22.

13. Grskovic M, Javaherian A, Strulovici B, Daley GQ. Induced pluripotent stem cells-opportunities for disease modelling and drug discovery. Nat Rev Drug Discov. 2011;10(12):91529.

14. Diecke S, Jung SM, Lee J, Ju JH. Recent technological updates and clinical applications of induced pluripotent stem cells. Korean J Intern Med. 2014 Sep;29(5):547-57.

15. Murry CE, Keller G. Differentiation of embryonic stem cells to clinically relevant populations: lessons from embryonic development. Cell. 2008;132(4):661-80.

16. Li X, Bai J, Ji X, Li R, Xuan Y, Wang Y. Comprehensive characterization of four different populations of human mesenchymal stem cells as regards their immune properties, proliferation and differentiation. Int J Mol Med. 2014 Sep;34(3):695-704.

17. Miles DC, de Vries NA, Gisler S, Lieftink C, Akhtar W, Gogola E, et al. TRIM28 is an Epigenetic Barrier to Induced Pluripotent Stem Cell Reprogramming. Stem Cells. 2017;35(1):147-57

18. Clarke MF, Dick JE, Dirks PB, Eaves CJ, Jamieson CH, Jones DL, et al. Cancer stem cells-perspectives on current status and future directions: AACR Workshop on cancer stem cells. Cancer Res. 2006 Oct 1;66(19):9339-44.

19. Virchow R. Die Cellularpathologie in ihrer Begrundung auf physiologische und pathologische Gewebelehre. Berlin, Germany: August Hirschwald; 1858.

20. Allegra E, Trapasso S. Cancer stem cells in head and neck cancer. OncoTargets and therapy. 2012;5:375-83.

21. Al-Hajj M, Wicha MS, Benito-Hernandez A, Morrison SJ, Clarke MF. Prospective identification of tumorigenic breast cancer cells. Proceedings of the National Academy of Sciences of the United States of America. 2003 Apr 1;100(7):3983-8.

22. Singh SK, Clarke ID, Terasaki M, Bonn VE, Hawkins C, Squire J, et al. Identification of a cancer stem cell in human brain tumors. Cancer Res. 2003 Sep 15;63(18):5821-8.

23. Collins AT, Berry PA, Hyde C, Stower MJ, Maitland NJ. Prospective identification of tumorigenic prostate cancer stem cells. Cancer Res. 2005 Dec 1;65(23):10946-51.

24. Dalerba P, Dylla SJ, Park IK, Liu R, Wang X, Cho RW, et al. Phenotypic characterization of human colorectal cancer stem cells. Proceedings of the National Academy of Sciences of the United States of America. 2007 Jun 12;104(24):10158-63.

25. Li C, Heidt DG, Dalerba P, Burant CF, Zhang L, Adsay V, et al. Identification of pancreatic cancer stem cells. Cancer Res. 2007 Feb 1;67(3):1030-7.

26. Ho MM, Ng AV, Lam S, Hung JY. Side population in human lung cancer cell lines and tumors is enriched with stem-like cancer cells. Cancer Res. 2007 May 15;67(10):4827-33.

27. Wicha MS, Liu S, Dontu G. Cancer Stem Cells: An Old Idea-A Paradigm Shift. Cancer Res. 2006 February 15, 2006;66(4):1883-90.

28. Costea DE, Tsinkalovsky O, Vintermyr OK, Johannessen AC, Mackenzie IC. Cancer stem cells - new and potentially important targets for the therapy of oral squamous cell carcinoma. Oral diseases. 2006 Sep;12(5):443-54.

29. Sayed SI, Dwivedi RC, Katna R, Garg A, Pathak KA, Nutting CM, et al. Implications of understanding cancer stem cell (CSC) biology in head and neck squamous cell cancer. Oral Oncology. 2011 4//;47(4):237-43.

30. Bissell MJ, Labarge MA. Context, tissue plasticity, and cancer: are tumor stem cells also regulated by the microenvironment? Cancer cell. 2005 Jan;7(1):17-23. 
31. Morrison SJ, Spradling AC. Stem Cells and Niches: Mechanisms That Promote Stem Cell Maintenance throughout Life. Cell.132(4):598-611.

32. Günthert U, Hofmann M, Rudy W, Reber S, Zöller M, Haußmann I, et al. A new variant of glycoprotein CD44 confers metastatic potential to rat carcinoma cells. Cell.65(1):13-24.

33. Shakib K, Schrattenholz A, Soskic V. Stem cells in head and neck squamous cell carcinoma. British Journal of Oral and Maxillofacial Surgery. 2011 10//;49(7):503-6.

34. Ding X-w, Wu J-h, Jiang C-p. ABCG2: A potential marker of stem cells and novel target in stem cell and cancer therapy. Life Sciences. 2010 4/24/;86(17-18):631-7.

35. Szafarowski T, Szczepanski MJ. Cancer stem cells in head and neck squamous cell carcinoma. Otolaryngologia polska The Polish otolaryngology. 2014;68(3):105-11.

36. Atena M, Reza AM, Mehran G. A Review on the Biology of Cancer Stem Cells. Stem Cell Discovery. 2014;4(04):83.

37. Kalluri R, Neilson EG. Epithelial-mesenchymal transition and its implications for fibrosis. The Journal of Clinical Investigation. 2003;112(12):1776-84.

38. Thiery JP. Epithelial-mesenchymal transitions in tumour progression. Nature reviews Cancer. 2002 Jun;2(6):442-54.

39. Radisky DC, LaBarge MA. Epithelial-mesenchymal transition and the stem cell phenotype. Cell stem cell. 2008 Jun 5;2(6):511-2.

40. Moreno-Bueno G, Portillo F, Cano A. Transcriptional regulation of cell polarity in EMT and cancer. Oncogene. 0000 //print;27(55):6958-69.

41. Perl AK, Wilgenbus P, Dahl U, Semb H, Christofori G. A causal role for E-cadherin in the transition from adenoma to carcinoma. Nature. 1998 Mar 12;392(6672):190-3.

42. Barth P, Schenck zu Schweinsberg T, Ramaswamy A, Moll R. CD34+ fibrocytes, $\alpha$-smooth muscle antigen-positive myofibroblasts, and CD117 expression in the stroma of invasive squamous cell carcinomas of the oral cavity, pharynx, and larynx. Virchows Archiv. 2004 2004/03/01;444(3):231-4.

43. Staibano S, Merolla F, Testa D, Iovine R, Mascolo M, Guarino V, et al. OPN//CD44v6 overexpression in laryngeal dysplasia and correlation with clinical outcome. Br J Cancer. 2007 11/06/online;97(11):1545-51.

44. Folkins C, Man S, Xu P, Shaked Y, Hicklin DJ, Kerbel RS. Anticancer Therapies Combining Antiangiogenic and Tumor Cell Cytotoxic Effects Reduce the Tumor Stem-Like Cell Fraction in Glioma Xenograft Tumors. Cancer Res. 2007 April 15, 2007;67(8):3560-4.

45. Chiou SH, Yu CC, Huang CY, Lin SC, Liu CJ, Tsai TH, et al. Positive correlations of Oct-4 and Nanog in oral cancer stem-like cells and high-grade oral squamous cell carcinoma. Clinical cancer research : an official journal of the American Association for Cancer Research. $2008 \mathrm{Jul}$ 1;14(13):4085-95.

46. Yu CC, Chang YC. Enhancement of cancer stem-like and epithelial-mesenchymal transdifferentiation property in oral epithelial cells with long-term nicotine exposure: reversal by targeting SNAIL. Toxicology and applied pharmacology. 2013 Feb 1;266(3):459-69.

47. Chen YS, Wu MJ, Huang CY, Lin SC, Chuang TH, Yu CC, et al. CD133/Src axis mediates tumor initiating property and epithelial-mesenchymal transition of head and neck cancer. PLoS ONE. 2011;6(11):e28053.

48. Trapasso S, Allegra E. Role of CD44 as a marker of cancer stem cells in head and neck cancer. Biologics : targets \& therapy. 2012;6:379-83.

49. Joshua B, Kaplan MJ, Doweck I, Pai R, Weissman IL, Prince ME, et al. Frequency of cells expressing CD44, a head and neck cancer stem cell marker: correlation with tumor aggressiveness. Head \& neck. 2012 Jan;34(1):42-9.

50. Chikamatsu K, Takahashi G, Sakakura K, Ferrone S, Masuyama K. Immunoregulatory properties of CD44+ cancer stem-like cells in squamous cell carcinoma of the head and neck. Head \& neck. 2011 Feb;33(2):208-15.

51. Picker LJ, Nakache M, Butcher EC. Monoclonal antibodies to human lymphocyte homing receptors define a novel class of adhesion molecules on diverse cell types. The Journal of cell biology. 1989 Aug;109(2):927-37.

52. Isacke CM, Yarwood H. The hyaluronan receptor, CD44. The international journal of biochemistry \& cell biology. 2002 7//;34(7):718-21.

53. Huet S, Groux H, Caillou B, Valentin H, Prieur AM, Bernard A. CD44 contributes to T cell activation. Journal of immunology (Baltimore, Md : 1950). 1989 Aug 1;143(3):798-801.

54. David Naor SBW-D, Muayad A. Zahalka, and Ronit Vogt Sionov. Involvement of CD44, a Molecule with a Thousand Faces, in Cancer Dissemination. In: Stern R, editor. Hyaluronan in Cancer Biology: Elsevier Science; 2009. p. 127-46. 
55. Franzmann EJ, Reategui EP, Pedroso F, Pernas FG, Karakullukcu BM, Carraway KL, et al. Soluble CD44 is a potential marker for the early detection of head and neck cancer. Cancer epidemiology, biomarkers \& prevention : a publication of the American Association for Cancer Research, cosponsored by the American Society of Preventive Oncology. 2007 Jul;16(7):1348-55.

56. Wang SJ, Bourguignon LY. Role of hyaluronan-mediated CD44 signaling in head and neck squamous cell carcinoma progression and chemoresistance. The American journal of pathology. 2011 Mar;178(3):956-63.

57. Jalkanen S, Wu N, Bargatze RF, Butcher EC. Human lymphocyte and lymphoma homing receptors. Annu Rev Med. 1987;38:467-76.

58. Ioachim E, Assimakopoulos D, Goussia AC, Peschos D, Skevas A, Agnantis NJ. Glycoprotein CD44 expression in benign, premalignant and malignant epithelial lesions of the larynx: an immunohistochemical study including correlation with Rb, p53, Ki-67 and PCNA. Histology and histopathology. 1999 Oct;14(4):1113-8.

59. Hirvikoski P, Tammi R, Kumpulainen E, Virtaniemi J, Parkkinen JJ, Tammi M, et al. Irregular expression of hyaluronan and its CD44 receptor is associated with metastatic phenotype in laryngeal squamous cell carcinoma. Virchows Archiv. 1999 Jan;434(1):37-44.

60. Allegra E, Trapasso S, Sacco A, Aragona T, Belfiore A, Garozzo A. ELISA detection of salivary levels of Cd44sol as a diagnostic test for laryngeal carcinomas. J Cancer Sci Ther. 2012;4:330-4.

61. Dall P, Heider KH, Hekele A, von Minckwitz G, Kaufmann M, Ponta H, et al. Surface protein expression and messenger RNA-splicing analysis of CD44 in uterine cervical cancer and normal cervical epithelium. Cancer Res. 1994 Jul 1;54(13):3337-41.

62. Guo YJ, Liu G, Wang X, Jin D, Wu M, Ma J, et al. Potential use of soluble CD44 in serum as indicator of tumor burden and metastasis in patients with gastric or colon cancer. Cancer Res. 1994 Jan 15;54(2):422-6.

63. Naor D, Nedvetzki S, Golan I, Melnik L, Faitelson Y. CD44 in cancer. Critical reviews in clinical laboratory sciences. 2002 Nov;39(6):527-79.

64. Wulfkuhle JD, Liotta LA, Petricoin EF. Proteomic applications for the early detection of cancer. Nature reviews Cancer. 2003 Apr;3(4):267-75.

65. Kawano T, Yanoma S, Nakamura Y, Ozeki A, Kokatsu T, Kubota A, et al. Soluble CD44 standard, CD44 variant 5 and CD44 variant 6 and their relation to staging in head and neck cancer. Acta Otolaryngol. 2005 Apr;125(4):392-7.

66. Franzmann EJ, Reategui EP, Pereira LHM, Pedroso F, Joseph D, Allen GO, et al. Salivary protein and solCD44 levels as a potential screening tool for early detection of head and neck squamous cell carcinoma. Head \& neck. 2012;34(5):687-95.

67. Warnakulasuriya S. Global epidemiology of oral and oropharyngeal cancer. Oral Oncology. 2009;45(4):309-16.

68. Ahmad AS, Ormiston-Smith N, Sasieni PD. Trends in the lifetime risk of developing cancer in Great Britain: comparison of risk for those born from 1930 to 1960. Br J Cancer. 2015;112(5):943-7.

69. Sharma D, Singh G. Squamous cell carcinoma of the oral cavity and oropharynx in young adults. Indian Journal of Cancer. 2016;53(3):399.

70. Torre LA, Bray F, Siegel RL, Ferlay J, Lortet-Tieulent J, Jemal A. Global cancer statistics, 2012. CA Cancer J Clin. 2015;65(2):87-108.

71. Patel SC, Carpenter WR, Tyree S, Couch ME, Weissler M, Hackman T, et al. Increasing incidence of oral tongue squamous cell carcinoma in young white women, age 18 to 44 years. J Clin Oncol. 2011 Apr 10;29(11):1488-94.

72. Ferlay J, Shin H-R, Bray F, Forman D, Mathers C, Parkin DM. Estimates of worldwide burden of cancer in 2008: GLOBOCAN 2008. International Journal of Cancer. 2010;127(12):2893-917.

73. Chaturvedi AK, Engels EA, Anderson WF, Gillison ML. Incidence trends for human papillomavirus-related and -unrelated oral squamous cell carcinomas in the United States. J Clin Oncol. 2008 Feb 1;26(4):612-9.

74. Guimaraes EP, de Carli ML, Sperandio FF, Hanemann JA, Pereira AA. Cyclin D1 and Ki-67 expression correlates to tumor staging in tongue squamous cell carcinoma. Med Oral Patol Oral Cir Bucal. 2015 Nov 01;20(6):e657-63.

75. Effiom OA, Adeyemo WL, Omitola OG, Ajayi OF, Emmanuel MM, Gbotolorun OM. Oral squamous cell carcinoma: a clinicopathologic review of 233 cases in Lagos, Nigeria. J Oral Maxillofac Surg. 2008 Aug;66(8):1595-9.

76. Chen J, Zhou J, Lu J, Xiong H, Shi X, Gong L. Significance of CD44 expression in head and neck cancer: a systemic review and meta-analysis. BMC cancer. 2014;14:15. 
77. Lingala S, Cui YY, Chen X, Ruebner BH, Qian XF, Zern MA, et al. Immunohistochemical staining of cancer stem cell markers in hepatocellular carcinoma. Exp Mol Pathol. 2010 Aug;89(1):27-35.

78. Kokko LL, Hurme S, Maula SM, Alanen K, Grenman R, Kinnunen I, et al. Significance of sitespecific prognosis of cancer stem cell marker CD44 in head and neck squamous-cell carcinoma. Oral Oncol. 2011 Jun;47(6):510-6.

79. Lindquist D, Ahrlund-Richter A, Tarjan M, Tot T, Dalianis T. Intense CD44 expression is a negative prognostic factor in tonsillar and base of tongue cancer. Anticancer Res. 2012 Jan;32(1):153-61.

80. Kanke M, Fujii M, Kameyama K, Kanzaki J, Tokumaru Y, Imanishi Y, et al. Role of CD44 variant exon 6 in invasion of head and neck squamous cell carcinoma. Archives of otolaryngology--head \& neck surgery. 2000 Oct;126(10):1217-23.

81. Maula SM, Luukkaa M, Grenman R, Jackson D, Jalkanen S, Ristamaki R. Intratumoral lymphatics are essential for the metastatic spread and prognosis in squamous cell carcinomas of the head and neck region. Cancer Res. 2003 Apr 15;63(8):1920-6.

82. Chen YW, Chen KH, Huang PI, Chen YC, Chiou GY, Lo WL, et al. Cucurbitacin I suppressed stem-like property and enhanced radiation-induced apoptosis in head and neck squamous carcinoma--derived CD44(+)ALDH1(+) cells. Mol Cancer Ther. 2010 Nov;9(11):2879-92.

83. Ghuwalewala S, Ghatak D, Das P, Dey S, Sarkar S, Alam N, et al. CD44 high CD24 low molecular signature determines the Cancer Stem Cell and EMT phenotype in Oral Squamous Cell Carcinoma. Stem Cell Research. 2016;16(2):405-17.

84. de Andrade NP, Rodrigues MFSD, Rodini CO, Nunes FD. Cancer stem cell, cytokeratins and epithelial to mesenchymal transition markers expression in oral squamous cell carcinoma derived from ortothopic xenoimplantation of CD44 high cells. Pathology-Research and Practice. 2016.

85. Ohkoshi E, Umemura N. Induced overexpression of CD44 associated with resistance to apoptosis on DNA damage response in human head and neck squamous cell carcinoma cells. International Journal of Oncology. 2017;50(2):387-95.

86. Baschnagel A, Tonlaar N, Wilson G, Williams L, Eskandari M. The Relationship Between CD44, EGFR, and c-MET Expression in Patients With Locally Advanced p16-Positive and p16-Negative Head and Neck Squamous Cell Carcinoma. International Journal of Radiation Oncology• Biology• Physics. 2016;94(4):938.

87. Dunkel J, Vaittinen S, Koivunen P, Laranne J, Mäkinen MJ, Tommola S, et al. Tumoral Expression of CD44 and HIF1 $\alpha$ Predict Stage I Oral Cavity Squamous Cell Carcinoma Outcome. Laryngoscope Investigative Otolaryngology. 2016.

88. Faber A, Barth C, Hormann K, Kassner S, Schultz JD, Sommer U, et al. CD44 as a stem cell marker in head and neck squamous cell carcinoma. Oncology reports. 2011 Aug;26(2):321-6.

89. Han J, Kioi M, Chu WS, Kasperbauer JL, Strome SE, Puri RK. Identification of potential therapeutic targets in human head \& neck squamous cell carcinoma. Head \& neck oncology. 2009;1:27.

90. Pries R, Witrkopf N, Trenkle T, Nitsch SM, Wollenberg B. Potential stem cell marker CD44 is constitutively expressed in permanent cell lines of head and neck cancer. In vivo (Athens, Greece). 2008 Jan-Feb;22(1):89-92.

91. Campos MS, Neiva KG, Meyers KA, Krishnamurthy S, Nor JE. Endothelial derived factors inhibit anoikis of head and neck cancer stem cells. Oral Oncol. 2012 Jan;48(1):26-32.

92. Soave DF, Oliveira da Costa JP, da Silveira GG, Ianez RC, de Oliveira LR, Lourenco SV, et al. CD44/CD24 immunophenotypes on clinicopathologic features of salivary glands malignant neoplasms. Diagn Pathol. 2013;8:29.

93. Oh SY, Kang HJ, Kim YS, Kim H, Lim YC. CD44-negative cells in head and neck squamous carcinoma also have stem-cell like traits. European journal of cancer (Oxford, England : 1990). 2013 Jan;49(1):272-80.

94. Bloor BK, Rajarajan A, Jaafary-Haghighat K, Odell EW. Transcription and expression of CD44 variant exons by oro-pharyngeal squamous cell carcinomas. Int J Oncol. 2002 Oct;21(4):907-13.

95. Saito H, Tsujitani S, Katano K, Ikeguchi M, Maeta M, Kaibara N. Serum concentration of CD44 variant 6 and its relation to prognosis in patients with gastric carcinoma. Cancer. 1998 Sep 15;83(6):1094-101.

96. Van Hal NL, Van Dongen GA, Ten Brink CB, Heider KH, Rech-Weichselbraun I, Snow GB, et al. Evaluation of soluble CD44v6 as a potential serum marker for head and neck squamous cell carcinoma. Clinical cancer research : an official journal of the American Association for Cancer Research. 1999 Nov;5(11):3534-41. 
97. Harn H-J, Ho L-I, Shyu R-Y, Yuan J-S, Lin F-G, Young T-H, et al. Soluble CD44 Isoforms in Serum as Potential Markers of Metastatic Gastric Carcinoma. Journal of Clinical Gastroenterology. 1996;22(2):107-10.

98. Amirghofran Z, Jalali SA, Hosseini SV, Vasei M, Sabayan B, Ghaderi A. Evaluation of CD44 and CD44v6 in colorectal carcinoma patients: soluble forms in relation to tumor tissue expression and metastasis. Journal of gastrointestinal cancer. 2008;39(1-4):73-8.

99. SHEEN-CHEN S-M, HUANG C-Y, CHAN Y-C, TSAI C-H, CHI S-Y, WU S-C, et al. An Evaluation of Focal Adhesion Kinase in Breast Cancer by Tissue Microarrays. Anticancer Res. 2013 March 1, 2013;33(3):1169-73.

100. Franzmann EJ, Lokeshwar VB. Biomarkers for detection and diagnosis of head and neck squamous cell carcinoma. Google Patents; 2016.

101. Patel S, Shah K, Mirza S, Shah K, Rawal R. Circulating tumor stem like cells in oral squamous cell carcinoma: An unresolved paradox. Oral Oncology. 2016;62:139-46.

102. Lin JT, Chang TH, Chang CS, Wang WH, Su BW, Lee KD, et al. Prognostic value of pretreatment CD44 mRNA in peripheral blood of patients with locally advanced head and neck cancer. Oral Oncol. 2010 May;46(5):e29-33.

103. Franzmann EJ, Reategui EP, Carraway KL, Hamilton KL, Weed DT, Goodwin WJ. Salivary soluble CD44: a potential molecular marker for head and neck cancer. Cancer epidemiology, biomarkers \& prevention : a publication of the American Association for Cancer Research, cosponsored by the American Society of Preventive Oncology. 2005 Mar;14(3):735-9.

104. Pereira LH, Adebisi IN, Perez A, Wiebel M, Reis I, Duncan R, et al. Salivary markers and risk factor data: a multivariate modeling approach for head and neck squamous cell carcinoma detection. Cancer Biomark. 2011;10(5):241-9.

105. Herold-Mende C, Seiter S, Born AI, Patzelt E, Schupp M, Zoller J, et al. Expression of CD44 splice variants in squamous epithelia and squamous cell carcinomas of the head and neck. J Pathol. 1996 May;179(1):66-73.

106. Yuce I, Bayram A, Cagli S, Canoz O, Bayram S, Guney E. The role of CD44 and matrix metalloproteinase-9 expression in predicting neck metastasis of supraglottic laryngeal carcinoma. Am J Otolaryngol. 2011 Mar-Apr;32(2):141-6.

107. Lein M, Jung K, Weiss S, Schnorr D, Loening S. Soluble CD44 variants in the serum of patients with urological malignancies. Oncology. 1997;54(3):226-30.

108. Molica S, Vitelli G, Levato D, Giannarelli D, Gandolfo GM. Elevated serum levels of soluble CD44 can identify a subgroup of patients with early B-cell chronic lymphocytic leukemia who are at high risk of disease progression. Cancer. 2001 Aug 15;92(4):713-9.

109. Hoffman RM. ACP Journal Club. Periodic PSA-based screening in men 55 to 69 years of age reduced prostate cancer mortality. Ann Intern Med. 2012 Jul 17;157(2):JC2-4.

110. Chen H, Shu HM, Chang ZL, Wang ZF, Yao HH, Zhu HM, et al. Efficacy of Pap test in combination with ThinPrep cytological test in screening for cervical cancer. Asian Pacific journal of cancer prevention : APJCP. 2012;13(4):1651-5. 